\title{
Influence of Ketamine on Catecholamine Secretion in the Perfused Rat Adrenal Medulla
}

\author{
Young-Yeob Ko' ${ }^{1}$, Yong-Hoon Jeong ${ }^{2}$, and Dong-Yoon Lim $^{2}$ \\ Departments of ${ }^{1}$ Internal Medicine (Cardiology), ${ }^{2}$ Pharmacology, College of Medicine, Chosun University, Gwangju 501-759, Korea
}

\begin{abstract}
The aim of the present study was to examine the effects of ketamine, a dissociative anesthetics, on secretion of catecholamines (CA) secretion evoked by cholinergic stimulation from the perfused model of the isolated rat adrenal gland, and to establish its mechanism of action, and to compare ketamine effect with that of thiopental sodium, which is one of intravenous barbiturate anesthetics. Ketamine $(30 \sim 300 \mu \mathrm{M})$, perfused into an adrenal vein for $60 \mathrm{~min}$, dose- and time-dependently inhibited the CA secretory responses evoked by ACh $(5.32 \mathrm{mM})$, high $\mathrm{K}^{+}$(a direct membranedepolarizer, $56 \mathrm{mM}$ ), DMPP (a selective neuronal nicotinic NN receptor agonist, $100 \mu \mathrm{M}$ ) and McN-A-343 (a selective muscarinic M1 receptor agonist, $100 \mu \mathrm{M}$ ). Also, in the presence of ketamine $(100 \mu \mathrm{M})$, the CA secretory responses evoked by veratridine (a voltage-dependent $\mathrm{Na}^{+}$channel activator, $100 \mu \mathrm{M}$ ), Bay-K-8644 (an L-type dihydropyridine $\mathrm{Ca}^{2+}$ channel activator, $10 \mu \mathrm{M}$ ), and cyclopiazonic acid (a cytoplasmic $\mathrm{Ca}^{2+}$-ATPase inhibitor, $10 \mu \mathrm{M}$ ) were significantly reduced, respectively. Interestingly, thiopental sodium $(100 \mu \mathrm{M})$ also caused the inhibitory effects on the CA secretory responses evoked by $\mathrm{ACh}$, high $\mathrm{K}^{+}$, DMPP, McN-A-343, veratridine, Bay-K-8644, and cyclopiazonic acid. Collectively, these experimental results demonstrate that ketamine inhibits the CA secretion evoked by stimulation of cholinergic (both nicotinic and muscarinic) receptors and the membrane depolarization from the isolated perfused rat adrenal gland. It seems likely that the inhibitory effect of ketamine is mediated by blocking the influx of both $\mathrm{Ca}^{2+}$ and $\mathrm{Na}^{+}$through voltage-dependent $\mathrm{Ca}^{2+}$ and $\mathrm{Na}^{+}$channels into the rat adrenal medullary chromaffin cells as well as by inhibiting $\mathrm{Ca}^{2+}$ release from the cytoplasmic calcium store, which are relevant to the blockade of cholinergic receptors. It is also thought that, on the basis of concentrations, ketamine causes similar inhibitory effect with thiopental in the CA secretion from the perfused rat adrenal medulla.
\end{abstract}

Key Words: Ketamine, thiopental, Catecholamine secretion, Adrenal medulla, Cholinergic receptors

\section{INTRODUCTION}

Ketamine is an intravenous anesthetic and also used clinically to induce a dissociative anesthesia. It has also been known to produce analgesic, psychotropic and sympathomimetic effects (Domino et al, 1965; Traber et al, 1968). During the initial phase of anesthesia, ketamine elicits a pronounced rise in blood pressure and heart rate (Gemperle et al, 1973; Lanning \& Harmel, 1975; Rust et al, 1978). Ketamine has also been shown to produce pressor effect (Domino et al, 1965; Corssen \& Domino, 1966; Kreuscher \& Gauch, 1967; Virtue et al, 1967; Traber et al, 1968) on the cardiovascular dynamics. The increase in systolic and diastolic pressure in animals, as well as in man, is mainly due to enhanced cardiac output (Domino et al, 1965; Virtue et al, 1967; Schwartz \& Horwitz, 1975). Moreover, A number of investigators have reported that ketamine suppresses $\left[{ }^{3} \mathrm{H}\right] \mathrm{NA}$ uptake in various sympathetic nervous tissues (Taube et al, 1975; Azzaro \& Smith, 1977; Garty et

Corresponding to: Dong-Yoon Lim, Department of Pharmacology, College of Medicine, Chosun University, 375, Seosuk-dong, Dong-gu, Gwangju 501-759, Republic of Korea. (Tel) 82-62-230-6335, (Fax) 82-62-227-4693, (E-mail) dylim@chosun.ac.kr al, 1990; Graf et al, 1995) and the adrenal medulla (Hara et al, 1998; Hara et al, 2002). Local administration of ketamine was also found to induce an increased norepinephrine (NE) levels in dialysate in anesthetized cats (Kitagawa et al, 2002).

In contrast, it has been known that ketamine produces depressor effect (McGrath et al, 1975; Diaz et al, 1976). The depressor effect has been ascribed to the direct action of ketamine on the heart (Dowdy \& Kaya, 1968; Traber et al, 1968; Goldberg et al, 1970; Schwartz \& Horwitz et al, 1975; Diaz et al. 1976) and blood vessels (Yamanaka \& Dowdy, 1974). Several reports showed that ketamine inhibited the CA secretion caused by acetylcholine receptor agonists from the isolated dog adrenals perfused with modified Locke's solution (Sumikawa et al, 1983), by nicotinic agonist at concentrations which did not alter secretion induced by elevated $\mathrm{K}^{+}$depolarization from cultured bovine adrenal chromaffin cells (Purifoy \& Holz, 1984), and by acute cold exposure anesthesia in adult rhesus monkeys (Kolka et al,

ABBREVIATIONS: CA, catecholamines; DMPP, 1.1-dimethyl-4-phenyl piperazinium iodide, methyl-1,4-dihydro-2; BAY-K8644, 6-dimethyl-3nitro-4-(2-trifluoromethyl-phenyl)-pyridine-5 -carboxylate; McN-A-343, 3-(m-cholro-phenyl-carbamoyl-oxy)-2-butynyltrimethyl ammonium chloride. 
1983). Ketamine also inhibited carbachol-induced ${ }^{45} \mathrm{Ca}$ influx and CA secretion from cultured bovine adrenal medullary cells in a concentration-dependent manner (Takara et al, 1986).

On the other hand, some investigators have reported that ketamne causes biphasic effects (McCarthy et al, 1965; Dowdy \& Kaya, 1968) on the cardiovascular dynamics. Okamoto and his co-workers (1996) demonstrated that ketamine depresses dopamine (DA) efflux related to membrane depolarization $\left(\mathrm{K}^{+}\right)$from rat pheochromocytoma (PC-12) cells as a model of sympathetic nervous system but it promotes a number of spontaneous DA efflux. In dogs, no alteration of circulating CA after injection of ketamine was found (Hensel et al, 1972; Klose \& Peter, 1973).

Anyway, it seems that there are so many conflicting results concerning effects of ketamine on the cardiovascular system and its neuraI regulatory systems. Therefore, the present study was designed to investigate the effects of ketamine on the CA secretion by cholinergic receptor stimulation and membrane depolarization from the perfused model of the isolated rat adrenal gland, and to clarify its mechanism of action.

\section{METHODS}

\section{Experimental procedure}

Male Sprague-Dawley rats, weighing 180 to 300 grams, were anesthetized with thiopental sodium $(40 \mathrm{mg} / \mathrm{kg})$ intraperitoneally. The adrenal gland was isolated by the methods described previously (Wakade, 1981). The abdomen was opened by a midline incision, and the upper adrenal gland and surrounding area were exposed by the placement of three-hook retractors. The stomach, intestine and portion of the liver were not removed, but pushed over to the lower side and covered by saline-soaked gauge pads and urine in bladder was removed in order to obtain enough working space for tying blood vessels and cannulations.

A cannula, used for perfusion of the adrenal gland, was inserted into the distal end of the renal vein after all branches of adrenal vein (if any), vena cava and aorta were ligated. Heparin $(400 \mathrm{IU} / \mathrm{ml})$ was injected into vena cava to prevent blood coagulation before ligating vessels and cannulations. A small slit was made into the adrenal cortex just opposite entrance of adrenal vein. Perfusion of the gland was started, making sure that no leakage was present, and the perfusion fluid escaped only from the slit made in adrenal cortex. Then the adrenal gland, along with ligated blood vessels and the cannula, was carefully removed from the animal and placed on a platform of a leucite chamber. The chamber was continuously circulated with water heated at $37 \pm 1^{\circ} \mathrm{C}$.

\section{Perfusion of adrenal gland}

The adrenal glands were perfused by means of ISCO pump (WIZ Co., U.S.A.) at a rate of $0.33 \mathrm{ml} / \mathrm{min}$. The perfusion was carried out with Krebs-bicarbonate solution of following composition $(\mathrm{mM})$ : $\mathrm{NaCl}, 118.4 ; \mathrm{KCl}, 4.7 ; \mathrm{CaCl}_{2}, 2.5$; $\mathrm{MgCl}_{2}, 1.18 ; \mathrm{NaHCO}_{3}, 25 ; \mathrm{KH}_{2} \mathrm{PO}_{4}, 1.2$; glucose, 11.7. The solution was constantly bubbled with $95 \% \mathrm{O}_{2}+5 \% \mathrm{CO}_{2}$ and the final $\mathrm{pH}$ of the solution was maintained at 7.4 7.5. The solution contained disodium EDTA $(10 \mu \mathrm{g} / \mathrm{ml})$ and ascorbic acid $(100 \mu \mathrm{g} / \mathrm{ml})$ to prevent oxidation of CA.

\section{Drug administration}

The perfusions of DMPP $\left(10^{-4} \mathrm{M}\right)$ for 2 minutes and/or a single injection of ACh $\left(5.32 \times 10^{-3} \mathrm{M}\right)$ and $\mathrm{KCl}\left(5.6 \times 10^{-2}\right.$ $\mathrm{M})$ in a volume of $0.05 \mathrm{ml}$ were made into perfusion stream via a three-way stopcock, respectively. McN-A-343 (10-4 M), veratridine $\left(10^{-4} \mathrm{M}\right)$, Bay-K-8644 $\left(10^{-5} \mathrm{M}\right)$ and cyclopiazonic acid $\left(10^{-5} \mathrm{M}\right)$ were also perfused for $4 \mathrm{~min}$, respectively. In the preliminary experiments, it was found that upon administration of the above drugs, secretory responses to ACh, $\mathrm{KCl}, \mathrm{McN}-\mathrm{A}-343$, veratridine, Bay-K-8644 and cyclopiazonic acid returned to pre-injection level in about $4 \mathrm{~min}$, but the responses to DMPP in $8 \mathrm{~min}$.

\section{Collection of perfusate}

As a rule, prior to stimulation with various secretagogues, the perfusate was collected for $4 \mathrm{~min}$ to determine the spontaneous secretion of CA (background sample). Immediately after the collection of the background sample, collection of the perfusates was continued in another tube as soon as the perfusion medium containing the stimulatory agent reached the adrenal gland. Stimulated sample's was collected for 4 to $8 \mathrm{~min}$. The amounts secreted in the background sample have been subtracted from that secreted from the stimulated sample to obtain the net secretion value of CA, which is shown in all of the figures.

To study the effect of ketamine or thiopental on the spontaneous and evoked secretion, the adrenal gland was perfused with Krebs solution containing ketamine or thiopental for $60 \mathrm{~min}$, and then the perfusate was collected for a certain period (background sample). Then the medium was changed to the one containing the stimulating agent or along with ketamine or thiopental, and the perfusates were collected for the same period as that for the background sample. The adrenal gland's perfusate was collected in chilled tubes.

\section{Measurement of catecholamines}

CA content of perfusate was measured directly by the fluorometric method of Anton and Sayre (Anton \& Sayre, 1962) without the intermediate purification alumina for the reasons described earlier (Wakade, 1981) using fluorospectrophotometer (Kontron Co., Milano, Italy).

A volume of $0.2 \mathrm{ml}$ of the perfusate was used for the reaction. The CA content in the perfusate of stimulated glands by secretagogues used in the present work was high enough to obtain readings several folds greater than the reading of control samples (unstimulated). The sample blanks were also lowest for perfusates of stimulated and non-stimulated samples. The content of CA in the perfusate was expressed in terms of norepinephrine (base) equivalents.

\section{Statistical analysis}

The statistical difference between the control and pretreated groups was determined by the Student's t-test. A $\mathrm{P}$-value of less than 0.05 was considered to represent statistically significant changes unless specifically noted in the text. Values given in the text refer to means and the standard errors of the mean (S.E.M.). The statistical analysis of the experimental results was made by computer program 
described by Tallarida and Murray (1987).

\section{Drugs and their sources}

The following drugs were used: ketamine hydrochloride (Yuhan Corporation, Seoul, Korea), acetylcholine chloride, 1.1-dimethyl-4-phenyl piperazinium iodide (DMPP), veratridine, norepinephrine bitartrate, methyl-1,4-dihydro-2,6dimethyl-3-nitro-4-(2-trifluoromethylphenyl)-pyridine-5carboxylate (BAY-K-8644) (Sigma Chemical Co., U.S.A.), cyclopiazonic acd, (3-(m-cholro-phenyl-carbamoyl-oxy)-2butynyltrimethyl ammonium chloride [McN-A-343] (RBI, U.S.A.), thiopental sodium (Choongwae Pharmaceutical Corporation, Seoul, Korea). Drugs were dissolved in distilled water (stock) and added to the normal Krebs solution as required except Bay-K-8644, which was dissolved in 99.5 $\%$ ethanol and diluted appropriately (final concentration of alcohol was less than $0.1 \%)$. Concentrations of all drugs used are expressed in terms of molar base.

\section{RESULTS}

Effect of ketamine on CA secretion evoked by ACh, excess $K^{+}, D M P P$ and $M c N-A-343$ from the perfused rat adrenal glands

After the perfusion with oxygenated Krebs-bicarbonate solution for $1 \mathrm{hr}$, basal CA release from the isolated perfused rat adrenal glands amounted to $22 \pm 2.1 \mathrm{ng} / 2 \mathrm{~min}$ $(n=8)$. It was attempted initially to examine the effects of ketamine itself on CA secretion from the perfused model of the rat adrenal glands. However, in the present study, ketamine $\left(3 \times 10^{-5} \sim 3 \times 10^{-4} \mathrm{M}\right)$ itself did not produce any effect on basal CA output from perfused rat adrenal glands (data not shown). Therefore, it was decided to investigate the effects of ketamine on cholinergic receptor stimulationas well as membrane depolarization-mediated CA secretion. Secretagogues were given at $15 \sim 20$ min-intervals. Ketamine was perfused for $60 \mathrm{~min}$.

When ACh $\left(5.32 \times 10^{-2} \mathrm{M}\right)$ in a volume of $0.05 \mathrm{ml}$ was injected into the perfusion stream, the amount of CA secreted was $1058 \pm 49 \mathrm{ng}$ for $4 \mathrm{~min}$. However, as shown in Fig. 1 (Upper), in the presence of ketamine $\left(3 \times 10^{-5} \sim 3 \times 10^{-4}\right.$ M) for $60 \mathrm{~min}$, ACh-evoked CA releasing responses were inhibited by $55 \%$ of the corresponding control release $(100 \%)$ in concentration- and time-dependent fashion. Also, $\mathrm{KCl}\left(5.6 \times 10^{-2} \mathrm{M}\right)$, the direct membrane-depolarizing agent, markedly evoked the CA secretion $(605 \pm 27 \mathrm{ng}$ for $0 \sim 4$ min). As shown in Fig. 1 (Lower), following the pretreatment with ketamine $\left(3 \times 10^{-5} \mathrm{M} \sim 3 \times 10^{-4} \mathrm{M}\right)$, excess $\mathrm{K}^{+}(5.6$ $\times 10^{-2} \mathrm{M}$ )-stimulated CA secretion was significantly inhibited to $54 \%$ of the control release. When perfused through the rat adrenal gland, DMPP $\left(10^{-4} \mathrm{M}\right)$, which is a selective nicotinic receptor agonist in autonomic sympathetic ganglia, evoked a sharp and rapid increase in CA secretion $(1,071 \pm 34 \mathrm{ng}$ for $0 \sim 8 \mathrm{~min})$. However, as shown in Fig. 2 (Upper), DMPP-stimulated CA secretion after pretreatment with ketamine was greatly reduced to $53 \%$ of the corresponding control release. McN-A-343 $\left(10^{-4} \mathrm{M}\right)$, which is a selective muscarinic M1-agonist (Hammer \& Giachetti, 1982), perfused into an adrenal gland for 4 min caused an increased CA secretion ( $486 \pm 20 \mathrm{ng}$ for $0 \sim 4 \mathrm{~min})$. However, McN-A-343-stimulated CA secretion in the presence of ket-

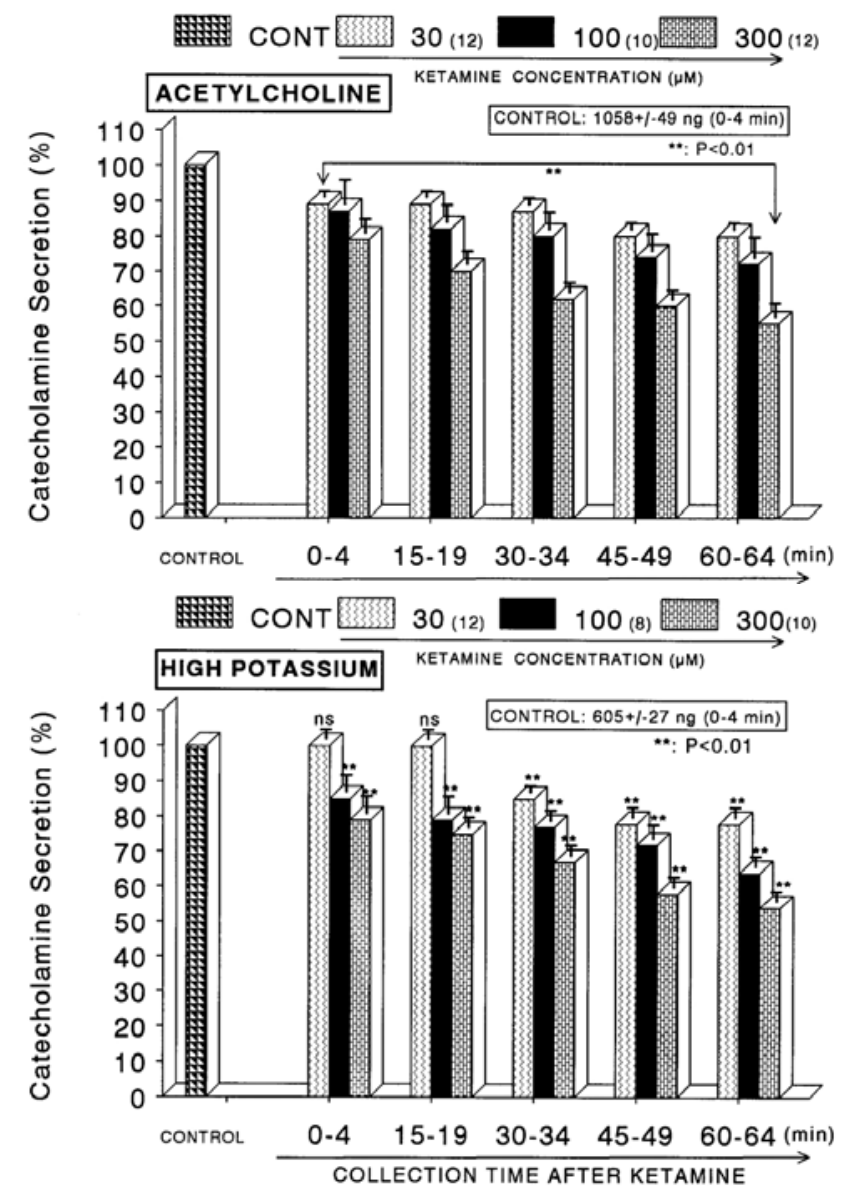

Fig. 1. Concentration-dependent effects of ketamine on the secretory responses of catecholamines (CA) from the perfused rat adrenal glands evoked by acetylcholine (ACh, Upper) and by high $\mathrm{K}^{+}$(Lower). CA secretion by a single injection of ACh $\left(5.32 \times 10^{-3}\right.$ M) or $\mathrm{K}^{+}(56 \mathrm{mM})$ in a volume of $0.05 \mathrm{ml}$ was evoked at $15 \mathrm{~min}$ intervals after preloading with 30,100 and $300 \mu \mathrm{M}$ of ketamine, respectively, for $60 \mathrm{~min}$ as indicated at an arrow mark. Numbers in the parenthesis indicate number of rat adrenal glands. Vertical bars on the columns represent the standard error of the mean (S.E.M.). Ordinate: the amounts of CA secreted from the adrenal gland (\% of control). Abscissa: collection time of perfusate (min). Statistical difference was obtained by comparing the corresponding control with each concentration-pretreated group of ketamine. Pefusates induced by $\mathrm{ACh}$ and high $\mathrm{K}^{+}$were collected for 4 minutes, respectively. ${ }^{* *} \mathrm{p}<0.01$.

amine was markedly depressed to $56 \%$ of the corresponding control secretion as depicted in Fig. 2 (Lower).

Effect of ketamine on CA secretion evoked by Bay-K8644 , cyclopiazonic acid and veratridine from the perfused rat adrenal glands

Since Bay-K-8644 is known to be a calcium channel activator, which enhances basal $\mathrm{Ca}^{2+}$ uptake (Garcia et al, 1984) and CA release (Lim et al, 1992), it was of interest to determine the effects of ketamine on Bay-K-8644-stimulated CA secretion from the isolated perfused rat adrenal glands. Bay-K-8644 $\left(10^{-5} \mathrm{M}\right)$-stimulated CA secretion in the presence of ketamine was inhibited to $72 \%$ of the corre- 


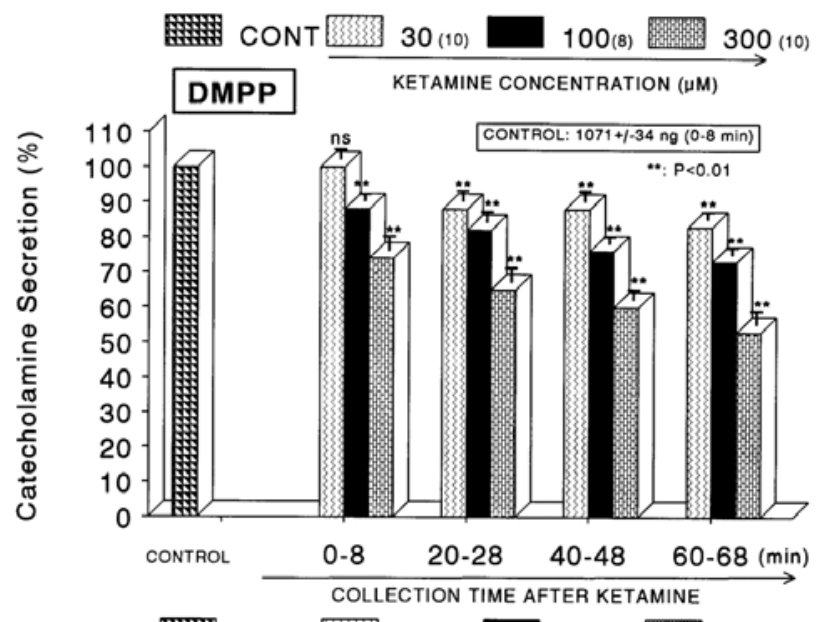

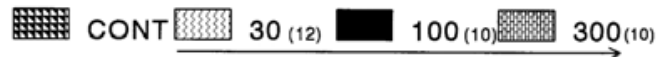

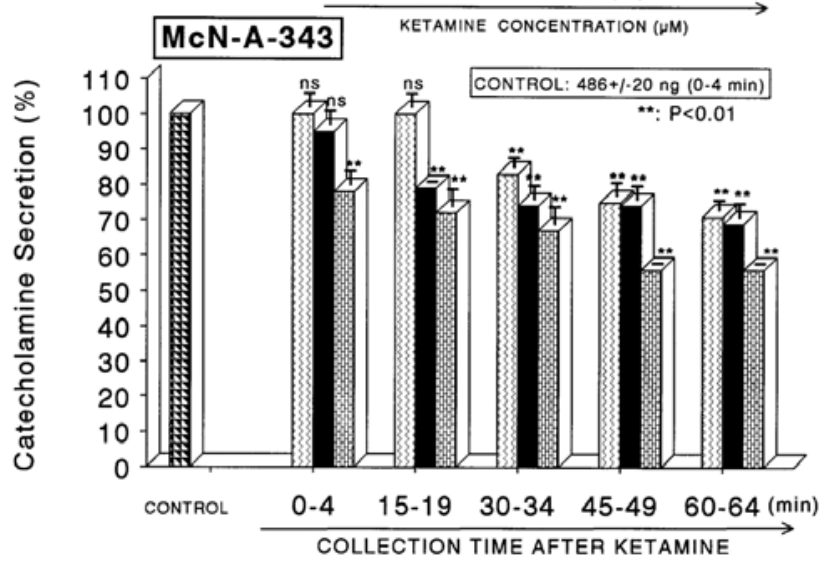

Fig. 2. Concentration-dependent effects of ketamine on the CA secretory responses evoked by DMPP (Upper) and McN-A-343 (Lower) from the perfused rat adrenal glands. The CA secretory responses by the perfusion of DMPP $\left(10^{-4} \mathrm{M}\right)$ and McN-A-343 $\left(10^{-4}\right.$ M) for $4 \mathrm{~min}$ at 20 and $15 \mathrm{~min}$ intervals were induced after preloading with 30,100 and $300 \mu \mathrm{M}$ of ketamine for $60 \mathrm{~min}$, respectively. Pefusates induced by DMPP and McN-A-343 were collected for 8 and 4 minutes, respectively. Other legends are the same as in Fig. $1 .{ }^{* *} \mathrm{P}<0.01$. ns: Statistically not significant.

sponding control release $(461 \pm 21 \mathrm{ng}$ for $0 \sim 4 \mathrm{~min})$ from 10 glands as shown in Fig. 3 (Upper).

Cyclopiazonic acid, a mycotoxin from Aspergillus and Penicillium, has been described as a highly selective inhibitor of $\mathrm{Ca}^{2+}$-ATPase in skeletal muscle sarcoplasmic reticulum (Goeger \& Riley, 1989; Seidler et al, 1989). The cyclopiazonic acid $\left(10^{-5} \mathrm{M}\right)$-evoked CA secretory response prior to treatment with ketamine was $435 \pm 21 \mathrm{ng}$ for $0-4$ min. As shown in Fig. 3 (Lower), however, in the presence of ketamine $\left(10^{-4} \mathrm{M}\right)$ in 10 rat adrenal glands, cyclopiazonic acid $\left(10^{-5} \mathrm{M}\right)$-evoked CA secretion was depressed to $71 \%$ of the control response.

It has been known that veratridine-induced $\mathrm{Na}^{+}$influx mediated through $\mathrm{Na}^{+}$channels increased $\mathrm{Ca}^{2+}$ influx via activation of voltage-dependent $\mathrm{Ca}^{2+}$ channels and produced the exocytotic secretion of CA in cultured bovine adrenal medullary cells (Wada et al, 1985a). As shown in Fig. 4, veratridine greatly produced CA secretion $(1,254 \pm 63$ ng for $0 \sim 4 \mathrm{~min})$. Ketamine $(100 \mu \mathrm{M})$ also attenuated vera-

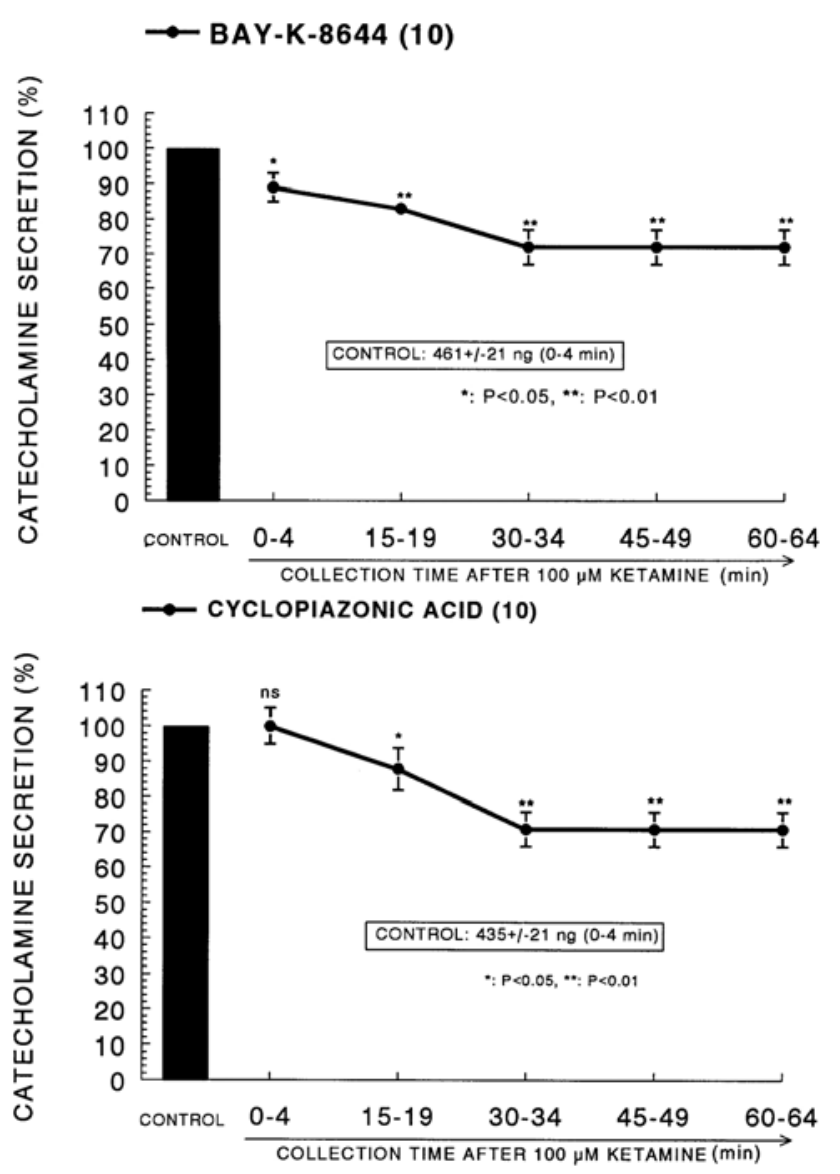

Fig. 3. Time course effect of ketamine on the CA release evoked by Bay-K-8644 (Upper) and cyclopiazonic acid (Lower) from the perfused rat adrenal glands. Bay-K-8644 $\left(10^{-5} \mathrm{M}\right)$ and cyclopiazonic acid $\left(10^{-5} \mathrm{M}\right)$ were perfused into an adrenal vein for $4 \mathrm{~min}$ at 15 min intervals after preloading with $100 \mu \mathrm{M}$ of ketamine for $60 \mathrm{~min}$, respectively. Other legends are the same as in Fig. $1 .{ }^{*} \mathrm{P}<0.05$, $* * \mathrm{P}<0.01$. ns: Statistically not significant.

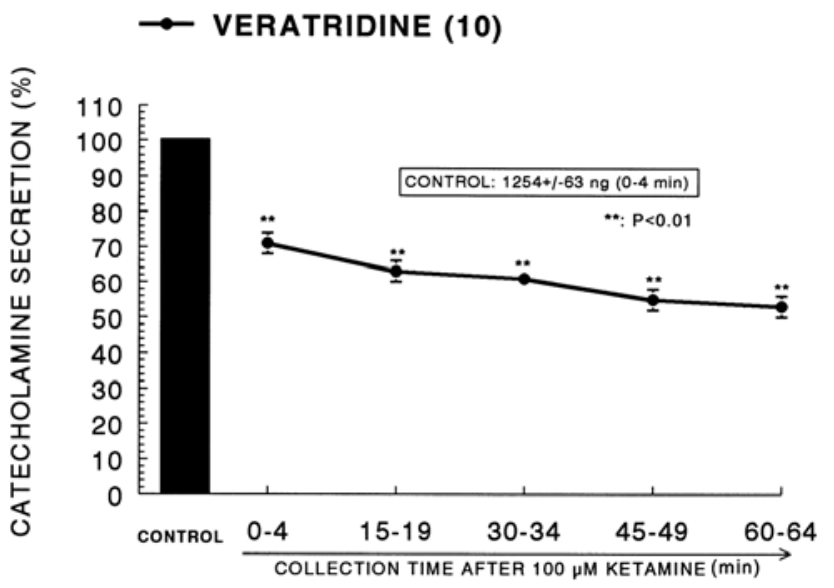

Fig. 4. Time course effect of ketamine on the CA release evoked by veratridine from the perfused rat adrenal glands. Veratridine $\left(10^{-4} \mathrm{M}\right)$ was perfused into an adrenal vein for $4 \mathrm{~min}$ at $15 \mathrm{~min}$ intervals after preloading with $100 \mu \mathrm{M}$ of ketamine for $60 \mathrm{~min}$. Other legends are the same as in Fig. $1 .{ }^{* *} \mathrm{P}<0.01$. 
tridine-induced CA secretion by $53 \%$ of the corresponding control release in a time-dependent manner.

Effect of thiopental on CA secretion evoked by ACh, excess $K^{+}, D M P P$ and $M c N-A-343$ from the perfused rat adrenal glands

In order to compare the effect of thiopental with that of ketamine, it was likely of interest to examine effect of thiopental on CA secretion evoked by ACh, high $\mathrm{K}^{+}$and DMPP from the isolated perfused rat adrenal glands. In order to test the effect of thiopental on cholinergic receptor-stimulated CA secretion as well as membrane depolarization-mediated secretion, concentration of $10^{-4} \mathrm{M}$ thiopental was loaded into the adrenal medulla. In the present study, ACh (5.32 mM)-evoked CA release before perfusion with thiopental $\left(10^{-4} \mathrm{M}\right)$ was $1440 \pm 125 \mathrm{ng}(0 \sim 4 \mathrm{~min})$ from 8 rat adrenal glands. However, in the presence of thiopental $\left(10^{-4} \mathrm{M}\right)$ for $60 \mathrm{~min}$, it was significantly attenuated to $71 \%$ of the control release (Fig. 5-Upper). High $\mathrm{K}^{+}(56 \mathrm{mM})$-evoked CA release under the presence of thiopental $\left(10^{-4}\right.$
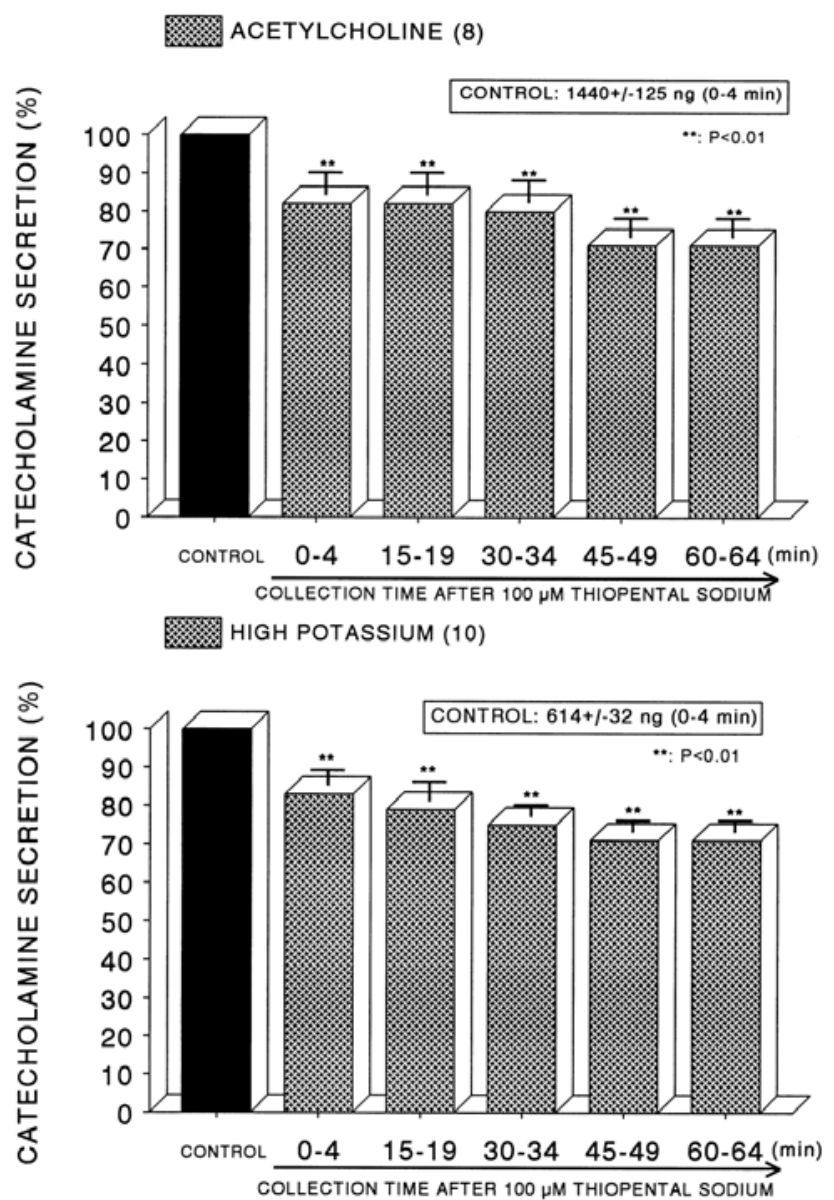

Fig. 5. Time course effect of of thiopental on the secretory responses of catecholamines (CA) from the perfused rat adrenal glands evoked by acetylcholine (ACh, Upper) and by high $\mathrm{K}^{+}$(Lower). CA secretion by a single injection of ACh $\left(5.32 \times 10^{-3} \mathrm{M}\right)$ or $\mathrm{K}^{+}(56 \mathrm{mM})$ in a volume of $0.05 \mathrm{ml}$ was evoked at 15 min intervals after preloading with $100 \mu \mathrm{M}$ thiopentall for $60 \mathrm{~min}$ as indicated at an arrow mark. Other legends are the same as in Fig. $1 .{ }^{* *} \mathrm{P}<0.01$.
M) was also reduced to $71 \%$ of the corresponding control secretion (614 $\pm 32 \mathrm{ng}, 0 \sim 4 \mathrm{~min})$ from 10 glands, as shown in Fig. 5 (Lower). In 6 rat adrenal glands, DMPP $\left(10^{-4} \mathrm{M}\right)$ perfused into the adrenal gland produced great CA secretion $(1,024 \pm 47 \mathrm{ng}, \quad 0 \sim 8 \mathrm{~min})$ prior to loading with thiopental. Following perfusion with thiopental $\left(10^{-4} \mathrm{M}\right)$ it was diminished to $75 \%$ of the corresponding control release (Fig. 6-Upper). Moreover, in the presence of thiopental $\left(10^{-4}\right.$ M), McN-A-343-evoked CA secretory response was also time-dependently inhibited by $72 \%$ of the control secretion (461 $\pm 21 \mathrm{ng}, 0 \sim 4 \mathrm{~min}$ ) from 10 glands, as shown in Fig. 6 (Lower).

Effect of thiopental on CA secretion evoked by Bay-K8644, cyclopiazonic acid and veratridine from the perfused rat adrenal glands

In the presence of thiopental $\left(10^{-4} \mathrm{M}\right)$, the secretory responses evoked by Bay-K-8644 $\left(10^{-5} \mathrm{M}\right)$ and cyclopiazonic acid $\left(10^{-5} \mathrm{M}\right)$ given into the adrenal gland for $4 \mathrm{~min}$ were greatly depressed to $69 \%$ and $71 \%$ of their the correspond-
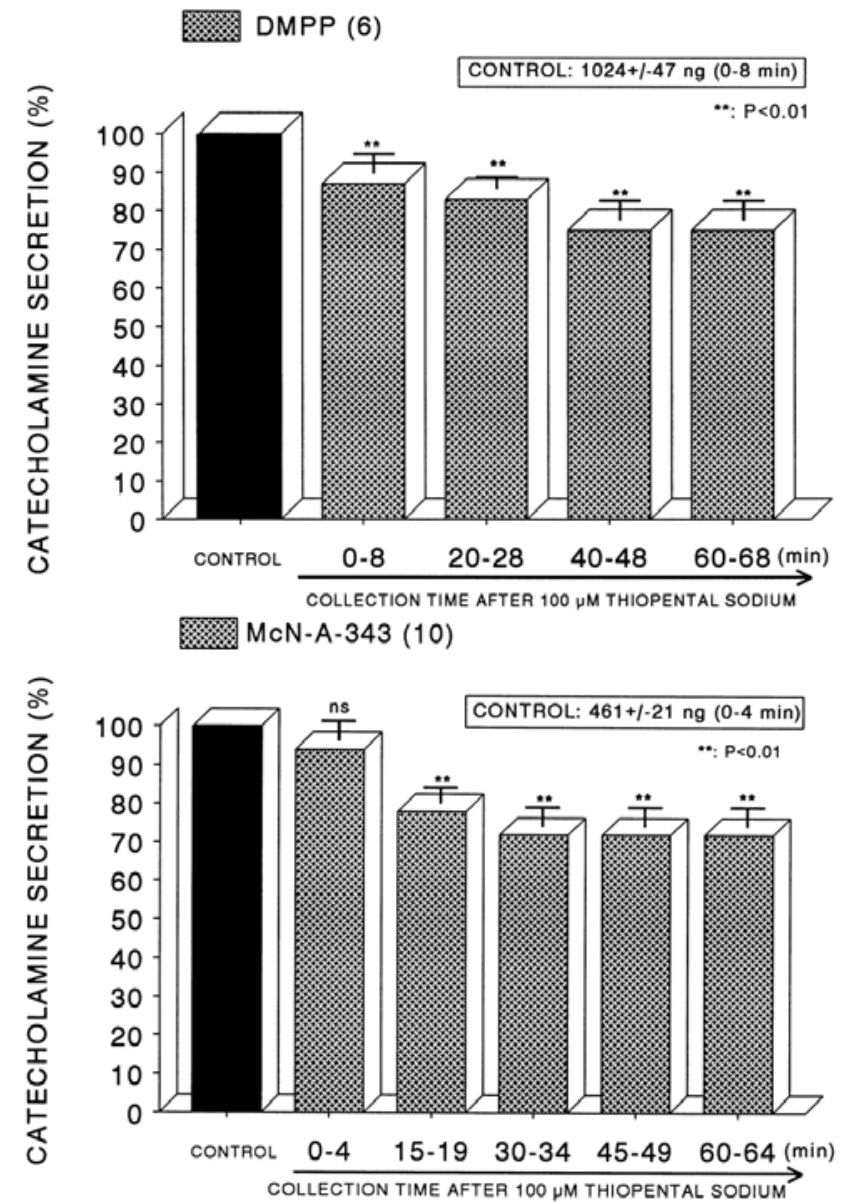

Fig. 6. Time course effect of of thiopental on the CA secretory responses evoked by DMPP (Upper) and McN-A-343 (Lower) from the perfused rat adrenal glands. The CA secretory responses by the perfusion of DMPP $\left(10^{-4} \mathrm{M}\right)$ and $\mathrm{McN}-\mathrm{A}-343\left(10^{-4} \mathrm{M}\right)$ for 4 min at 20 and 15 min intervals were induced after preloading with $100 \mu \mathrm{M}$ thiopental for $60 \mathrm{~min}$, respectively. Other legends are the same as in Fig. $1 .{ }^{* *} \mathrm{P}<0.01$. ns: Statistically not significant. 


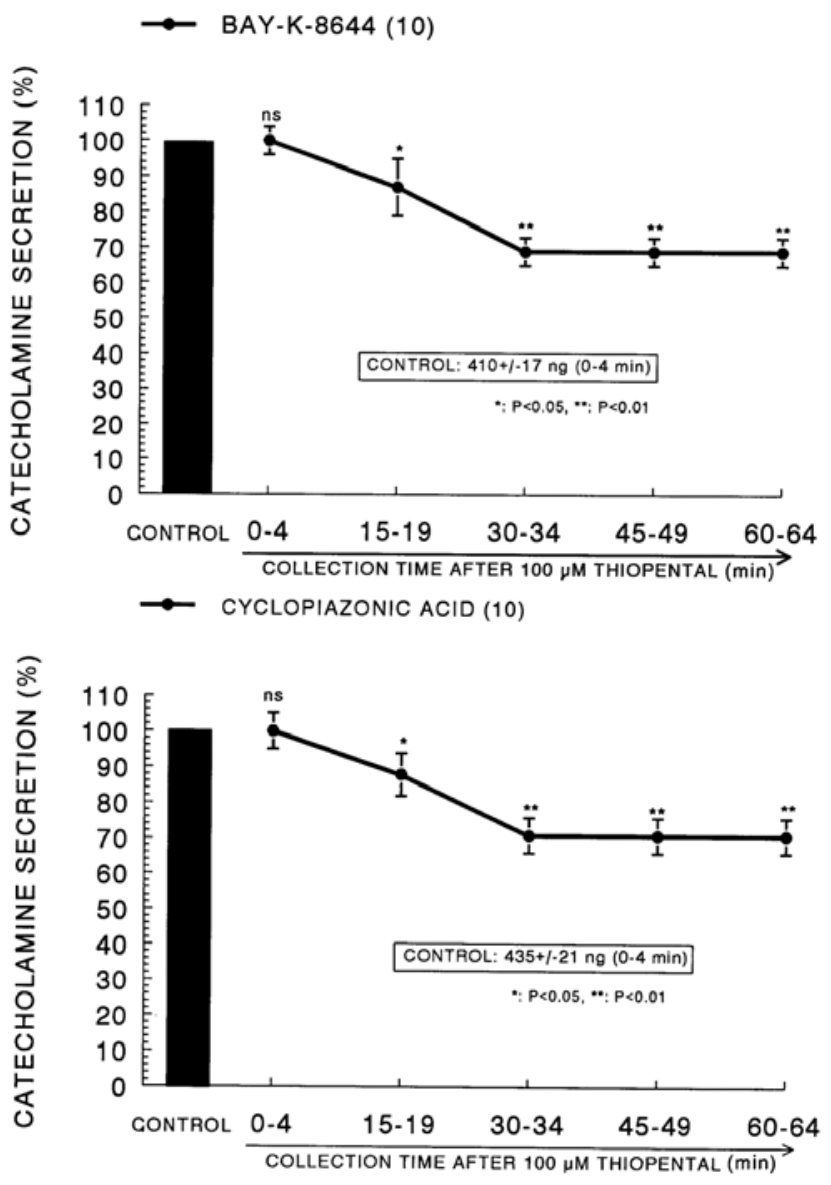

Fig. 7. Time course effect of thiopental on the CA release evoked by Bay-K-8644 (Upper) and cyclopiazonic acid (Lower) from the perfused rat adrenal glands. Bay-K-8644 $\left(10^{-5} \mathrm{M}\right)$ and cyclopiazonic acid $\left(10^{-5} \mathrm{M}\right)$ were perfused into an adrenal vein for $4 \mathrm{~min}$ at 15 min intervals after preloading with $100 \mu \mathrm{M}$ of thiopental for 60 min, respectively. Other legends are the same as in Fig. 1. ${ }^{*} \mathrm{P}<0.05$, $* * \mathrm{P}<0.01 . \mathrm{ns}$ : Statistically not significant.

ing control responses $(410 \pm 17 \mathrm{ng}$ for $4 \mathrm{~min}$ and $435 \pm 21 \mathrm{ng}$ for $4 \mathrm{~min}$ ), respectively (Fig. 7). The CA secretion evoked by veratridine $\left(10^{-4} \mathrm{M}\right)$, an activator of $\mathrm{Na}^{+}$channels, was greatly increased to $1203 \pm 44 \mathrm{ng}$ for 0 -4 min before loading of ketamine. However, in the presence of thiopental, it was inhibited to $53 \%$ of the corresponding control secretion, as shown in Fig. 8.

\section{DISCUSSION}

The experimental results obtained from the present study demonstrate that ketamine dose- and time-dependently inhibits the CA secretion evoked by the stimulation of cholinergic (both nicotinic and muscarinic) receptors and direct membrane depolarization in concentration- and time-dependent manners from the isolated perfused rat adrenal gland. It seems likely that the inhibitory effect of ketamine is mediated by blocking both the calcium influx into the rat adrenal medullary chromaffin cells and $\mathrm{Ca}^{2+}$ release from the cytoplasmic calcium store through the blockade of voltage-dependent $\mathrm{Ca}^{2+}$ channels as well as voltage- de-

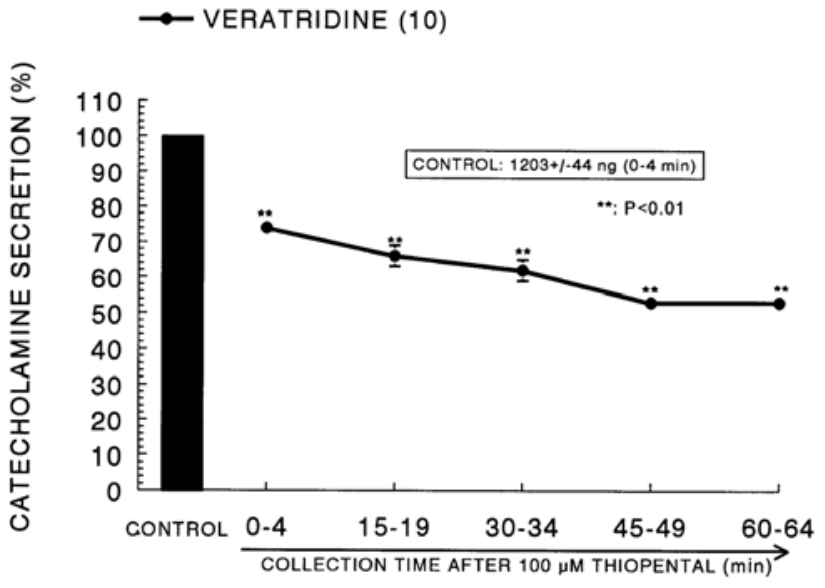

Fig. 8. Time course effect of thiopental on the CA release evoked by veratridine from the perfused rat adrenal glands. Veratridine $\left(10^{-4} \mathrm{M}\right)$ was perfused into an adrenal vein for $4 \mathrm{~min}$ at $15 \mathrm{~min}$ intervals after preloading with $100 \mu \mathrm{M}$ of thiopental for $60 \mathrm{~min}$. Other legends are the same as in Fig. $1 .{ }^{* *} \mathrm{P}<0.01$.

pendent $\mathrm{Na}^{+}$channels on the rat adrenal medullary chromaffin cells, which are relevant to the blockade of cholinergic receptors.

The present results are in agreement with the findings by Purifoy and Holz (1984) that ketamine inhibited the CA secretion evoked by a nicotinic agonist DMPP in cultured bovine adrenal chromaffin cells in a noncompetitive fashion. In the present work, the in vitro concentrations of ketamine for inhibiting the effect of various secretagogues used in the rat perfused adrenal medulla are not much different from those attained in vivo in laboratory animals and humans (Dowdy \& Kaya, 1968: Traber et al, 1968; Goldberg et al, 1970: Yamanaka \& Dowdy, 1974; Schwartz \& Horwitz et al, 1975; McGrath et al, 1975; Diaz et al. 1976; Kolka et al, 1983; Sumikawa et al, 1983; Purifoy \& Holz, 1984; Takara et al, 1986).

In the present work, ketamine concentration-dependently suppressed the CA secretory responses evoked by ACh and DMPP. These results suggest that ketamine inhibits the nicotinic receptor stimulation-induced CA secretion by interfering with the influx of $\mathrm{Ca}^{2+}$. In this experiment, ketamine as well as thiopental also depressed the CA secretion induced by Bay-K-8644, which is found to enhance the CA release by increasing $\mathrm{Ca}^{2+}$ influx through L-type $\mathrm{Ca}^{2+}$ channels in chromaffin cells (Garcia et al, 1984). These findings that ketamine inhibited the CA secretion evoked by high $\mathrm{K}^{+}$and also by Bay-K-8644 suggest that ketamine directly inhibits the voltage-dependent $\mathrm{Ca}^{2+}$ channels through nicotinic receptor stimulation, just like $\mathrm{Ca}^{2+}$ channel blockers (Cena et al, 1983), which have direct actions on voltage-dependent $\mathrm{Ca}^{2+}$ channels. In the bovine chromaffin cells, stimulation of nicotinic, but not muscarinic ACh receptors is known to cause CA secretion by increasing $\mathrm{Ca}^{2+}$ influx largely through voltage-dependent $\mathrm{Ca}^{2+}$ channels (Oka et al, 1979; Burgoyne, 1984). Some previous reports also showed that Bay-K-8644 selectively potentiates the CA secretory responses mediated through the activation of voltage-sensitive $\mathrm{Ca}^{2+}$ channels; during nicotine or high-K stimulation (Ladona et al, 1987; Uceda et al, 1992). Therefore, it seems that ketamine inhibits DMPP-evoked CA secretion through inhibition of $\mathrm{Ca}^{2+}$ influx through volt- 
age-dependent $\mathrm{Ca}^{2+}$ channels activated by nicotinic ACh receptors. However, in the present study, thiopental also inhibited the secretion of CA from the perfused rat adrenal glands induced by Bay-K-8644 as well as high potassium, suggesting that both ketamine and thiopental suppress influx of $\mathrm{Ca}^{2+}$ induced by an activator of L-type voltage-sensitive $\mathrm{Ca}^{2+}$ channels such as Bay-K-8644, which is thought to pass through voltage-sensitive $\mathrm{Ca}^{2+}$ channels and to stimulate CA secretion.

In support of this idea, it has been shown that ketamine also inhibited the carbachol-induced influx of ${ }^{45} \mathrm{Ca}^{2+}$ with a concentration-inhibition curve similar to that for the CA secretion (Takara et al, 1986). This finding suggests that ketamine inhibited the carbachol-induced secretion of CA by interfering with the influx of $\mathrm{Ca}^{2+}$. However, it is not likely that ketamine suppressed directly the voltage-dependent $\mathrm{Ca}^{2+}$ channels themselves since the influx of ${ }^{45} \mathrm{Ca}^{2+}$ due to high $\mathrm{K}^{+}$was not affected by ketamine. This result is not in agreement with that of the present work. This difference is not clearly find out, but seems to be difference between concentrations, preparations and the experimental methods used in studies. It has been reported that the impairment of the righting reflex in rats anesthetized with ketamine was reversed when the free plasma concentration of the anesthetic decreased to $17 \mu \mathrm{M}$ (Cohen et al, 1973). However, a much higher concentration of ketamine in plasma $(60 \mu \mathrm{M})$ was also demonstrated in patients $5 \mathrm{~min}$ after the intravenous injection of $2 \mathrm{mg} / \mathrm{kg}$ (Idvall et al, 1979). In humans, the free plasma concentration of ketamine 5 min after intravenous injection of 2.5 $\mathrm{mg} / \mathrm{kg}$ was approximately $103 \mu \mathrm{M}$ (Wieber et al, 1975). Concentrations of ketamine between $20 \mu \mathrm{M}$ and $100 \mu \mathrm{M}$ are attained during anesthesia (Domino et al, 1982).

The mechanism by which the stimulation of ACh receptors activates voltage-dependent $\mathrm{Ca}^{2+}$ channels in adrenal medullary cells is well understood. It has also been shown that ACh depolarizes chromaffin cell membranes and that this is dependent on the inward movement of $\mathrm{Na}^{+}$ into the cells (Douglas et al, 1967). Kidokoro and his co-workers (1982) demonstrated that $\mathrm{ACh}$ generates $\mathrm{Na}^{+}$ -dependent action potentials and that these are mediated by nicotinic (but not muscarinic) ACh receptors. Taking these previous observations into account, it has been suggested that the influx of $\mathrm{Na}^{+}$via nicotine receptor-associated ionic channels leads to the activation of voltage-dependent $\mathrm{Ca}^{2+}$ channels by altering the membrane potentials (Wada et al, I985b). In the present study, ketamine suppressed the veratridine-evoked CA secretory response. This result suggests that the inhibition by ketamine of the veratridine-evoked $\mathrm{CA}$ secretion as well as by $\mathrm{ACh}$ and DMPP is responsible for the inhibition of $\mathrm{Ca}^{2+}$ influx and the CA secretion. Ketamine was also found to inhibit the carbachol-induced influx of ${ }^{22} \mathrm{Na}^{+}$at the same concentrations as it inhibited carbachol- induced ${ }^{45} \mathrm{Ca}^{2+}$ influx and the CA secretion (Takara et al, 1986). It has also been reported to depress synaptic transmission in the neuromuscular junction by interacting with the ionic channels of nicotine receptors (Maleque et al, 1981; Volle et aI., 1982). Therefore, it seems likely that the predominant site of action of ketamine is nicotinic receptor-gated ionic channel in the rat adrenomedullary chromaffin cells.

Takara and his colleagues (1986) also found that ketamine, at higher concentrations, reduced the veratridine-induced influx of ${ }^{22} \mathrm{Na}^{+},{ }^{45} \mathrm{Ca}^{2+}$ and the secretion of CA with a similar potency (IC50 $260 \mu \mathrm{M}$ ). Veratridine-in- duced influx of $\mathrm{Na}^{+}$is a requisite for triggering $\mathrm{Ca}^{2+}$ influx and the CA secretion (Wada et al, 1985a; 1985b). Therefore, the inhibition by ketamine of voltage-dependent $\mathrm{Na}^{+}$channels is responsible for the inhibition of $\mathrm{Ca}^{2+}$ influx and the $\mathrm{CA}$ secretion. Voltage-dependent $\mathrm{Na}^{+}$channels are indispensable for axonal conduction in central and peripheral neurons. However, based on the present results, since ketamine depressed the veratridine-evoked CA secretion at concentrations $(30 \sim 100 \mu \mathrm{M})$ used clinically, it seems likely that the inhibition of voltage-dependent $\mathrm{Na}^{+}$channels might be produced during clinical anesthesia.

In in vivo (Clanachan \& McGrath, 1976) and in vitro (Juang et al, 1980; Mahmoodi et al, 1980) experiments, ketamine has been shown to depress synaptic transmission at peripheral sympathetic ganglia. In cultured adrenal medullary cells, which are devoid of preganglionic innervation, the effects of ketamine are confined to the postsynaptic action of the anesthetic. In this study, it looks likely that, in the isolated perfused adrenal gland, ketamine acts on the postsynaptic membrane and could selectively inhibit nicotine receptor-associated ionic channels. The present results are consistent with those of electrophysiological experiments (Gallagher et al, 1976): i.e. ketamine suppressed the postganglionic action potentials elicited by iontophoretically applied ACh, while ketamine had little effect on preganglionic axonal conduction.

In the present study, both ketamine and thiopental also suppressed the CA secretion evoked by McN-A-343, a selective muscarinic M1-receptor agonist. Generally, it has been shown that muscarinic stimulation generates a depolarizing signal which triggers the firing of action potentials, resulting in the increased CA release in the rat chromaffin cells (Akaike et al, 1990; Lim \& Hwang, 1991). The elevation of intracellular $\mathrm{Ca}^{2+}$ mobilized from intracellular storage sites is thought to contribute to the muscarinic receptor-mediated secretion of adrenal CA (Harish et al, 1987; Misbahuddin et al, 1985; Nakazato et al, 1988). Furthermore, it has been shown that muscarinic receptor activation depolarizes the adrenal chromaffin cells of chickens (Knight \& Baker, 1986), rats (Akaike et al, 1990), and guinea pigs (Inoue \& Kuriyama, 1991). In terms of these findings, in this study, the inhibitory effect of ketamine on the muscarinic receptor-mediated secretion of CA can be explained in the same manner as for the nicotinic receptor-mediated secretion.

In this study, both ketamine and thiopental also inhibited the CA secretory response evoked by cyclopiazonic acid, which is known to be a highly selective inhibitor of $\mathrm{Ca}^{2+}$-ATPase in skeletal muscle sarcoplasmic reticulum (Goeger \& Riley, 1989; Seidler et al, 1989) and a valuable pharmacological tool for investigating intracellular $\mathrm{Ca}^{2+}$ mobilization and ionic currents regulated by intracellular $\mathrm{Ca}^{2+}$ (Suzuki et al, 1992). Therefore, this result suggests that the inhibitory effect of ketamine on the CA secretion evoked by cholinergic muscarinic stimulation might be associated with the mobilization of intracellular $\mathrm{Ca}^{2+}$ in the rat adrenal chromaffin cells. This indicates that ketamine has an inhibitory effect on the release of $\mathrm{Ca}^{2+}$ from the intracellular pools induced by stimulation of muscarinic ACh receptors, which is weakly responsible for the CA secretion. It has been shown that $\mathrm{Ca}^{2+}$-uptake into intracellular storage sites susceptible to caffeine (Ilno, 1989) is almost completely abolished by treatment with cyclopiazonic acid during the proceeding $\mathrm{Ca}^{2+}$ load (Suzuki et al, 1992). This is consistent with the findings obtained in skinned smooth 
muscle fibers of the longitudinal layer of the guinea-pig ileum, where $\mathrm{Ca}^{2+}$-uptake was also inhibited by cylopiazonic acid (Uyama et al, 1992). Suzuki and his coworkers (1992) have shown that cyclopiazonic acid easily penetrates into the cytoplasm through the plasma membrane and reduces $\mathrm{Ca}^{2+}$-ATPase activity in sarcoplasmic/endoplasmic reticulum, resulting in increase in the subsequent $\mathrm{Ca}^{2+}$ release from those storage sites. Moreover, in bovine adrenal chromaffin cells, stimulation of muscarinic ACh receptors is also proposed to cause activation of phosphoinositide metabolism, resulting in the formation of inositol 1,4,5-trisphosphate, which induces the mobilization of $\mathrm{Ca}^{2+}$ from the intracellular pools (Cheek et al, 1989; Challis et al, 1991). However, in the present study, it is uncertain whether the inhibitory effect of ketamine on $\mathrm{Ca}^{2+}$ mobilization from intracellular pools is due to its direct effect on the PI response or an indirect effect.

In conclusion, these experimental results demonstrate that ketamine inhibits the CA secretion evoked by stimulation of cholinergic (both nicotinic and muscarinic) receptors and the membrane depolarization from the isolated perfused rat adrenal gland. It seems likely that the inhibitory effect of ketamine is mediated by blocking the calcium influx through voltage-dependent $\mathrm{Ca}^{2+}$ channels into the rat adrenal medullary chromaffin cells as well as $\mathrm{Ca}^{2+}$ release from the cytoplasmic calcium store partly through the blockade of voltage-dependent $\mathrm{Na}^{+}$channels on the rat adrenal medullary chromaffin cells, which are at least relevant to the blockade of cholinergic receptors.

\section{ACKNOWLEDGMENTS}

This study was supported partly by Chosun University (2006).

\section{REFERENCES}

Akaike A, Mine Y, Sasa M, Takaori S. Voltage and current clamp studies of muscarinic and nicotinic excitation of the rat adrenal chromaffin cells. J Pharmacol Exp Ther 255: 333-339, 1990

Anton AH, Sayre DF. A study of the factors affecting the aluminum oxidetrihydroxy indole procedure for the analysis of catecholamines. J Pharmacol Exp Ther 138: 360-375, 1962

Azzaro AJ, Smith DJ. The inhibitory action of ketamine $\mathrm{HCl}$ on $\left[{ }^{3} \mathrm{H}\right] 5$-hydroxytryptamine accumulation by rat brain synaptosomal-rich fractions: comparison with $\left[{ }^{3} \mathrm{H}\right]$ catecholamine and $\left[{ }^{3} \mathrm{H}\right]^{\gamma}$-aminobutyric acid uptake. Neuropharmacology 16: 349356, 1977

Burgoyne RD. Mechanisms of secretion from adrenal chromaffin cells. Biochim Biophys Acta 779: 201-216, 1984

Cena V, Nicolas GP, Sanchez-Garcia P, Kirpekar SM, Garcia AG. Pharmacological dissection of receptor-associated and voltagesensitive ionic channels involved in catecholamine release. Neuroscience 10: 1455-1462, 1983

Challis RA, Jones JA, Owen PJ, Boarder MR. Changes in inositol 1,4,5-trisphosphate and inositol 1,3,4,5-tetrakisphosphate mass accumulations in cultured adrenal chromaffin cells in response to bradykinin and histamine. J Neurochem 56: 1083-1086, 1991

Cheek TR, O'Sullivan AJ, Moreton RB, Berridge MJ, Burgoyne RD. Spatial localization of the stimulus-induced rise in cytosolic $\mathrm{Ca}^{2+}$ in bovine adrenal chromaffin cells: Distinct nicotinic and muscarinic patterns. FEBS Lett 247: 429-434, 1989

Clanachan AS, McGrath JC. Effects of ketamine on the peripheral autonomic nervous system of the rat. $\mathrm{Br} J$ Pharmacol 58: 247252, 1976
Cohen ML, Chan SL, Way WL, Trevor AJ. Distribution in the brain and metabolism of ketamine in the rat after intravenous administration. Anesthesiology 39: 370-376, 1973

Corssen G, Domino EF. Dissociative anesthesia: further pharmacologic studies and first clinical experience with the phencyclidine derivative CI-581. Anesth Analg 45: 29-40, 1966

Diaz FA, Bianco JA, Bello A, Beer N, Velarde H, Izquierdo JP, Jaen R. Effects of ketamine on canine cardiovascular function. $\mathrm{Br} J$ Anaesth 48: 941-946, 1976

Domino EF, Chodoff P, Corssen G. Pharmacologic effects of CI-581, a new dissociative anesthetic in man. Clin Pharmacol Ther 6: 279-291, 1965

Domino EF, Zsigmond EK, Domino LE, Domino KE, Kothary SP, Domino SE. Plasma levels of ketamine and two of its metabolites in surgical patients using a gas chromatographic mass fragmentographic assay. Anesth Analg 61: 87-92, 1982

Douglas WW, Kanno T, Sampson SR. Influence of the ionic environment on the membrane potential of adrenal chromaffin cells and on the depolarizing effect of acetylcholine. $J$ Physiol 191: $107-121,1967$

Dowdy EG, Kaya K. Studies of the mechanism of cardiovascular responses to CI-581. Anesthesiology 29: 931-943, 1968

Gallagher JP, Dun N, Higashi H, Nisihi S. Actions of ketamine on synaptic transmission in frog sympathetic ganglia. Neuropharmacology 15: 139-143, 1976

Garcia AG, Sala F, Reig JA, Viniegra S, Frias J, Fonteriz R, Gandia L. Dihydropyridine Bay-K-8644 activates chromaffin cell calcium channels. Nature 309: 69-71, 1984

Garty M, Deka-Starosta A, Stull R, Kopin IJ, Goldstein DS. Effects of general anesthetics on plasma levels of catechols in intact and in adrenal-demedullated rats. Biogenic Amines 7: 435-443, 1990

Gemperle M, Szappanyos G, Rifat K. Neuroleptanesthesia in gerontosurgery. Int Anesthesiol Clin 11: 125-138, 1973

Goeger DE, Riley RT. Interaction of cyclopiazonic acid with rat skeletal muscle sarcoplasmic reticulum vesicles. Effect on $\mathrm{Ca}^{2+}$ binding and $\mathrm{Ca}^{2+}$ permeability. Biochem Pharmacol 38: 39954003, 1989

Goldberg AH, Keane PW, Phear WP. Effects of ketamine on contractile performance and excitability of isolated heart muscle. J Pharmacol Exp Ther 175: 388-394, 1970

Graf BM, Vicenzi MN, Martin E, Bosnjak ZJ, Stowe DF. Ketamine has stereospecific effects in the isolated perfused guinea pig heart. Anesthesiology 82: 1426-1437, 1995

Hammer R, Giachetti A. Muscarinic receptor subtypes: M1 and M2 biochemical and functional characterization. Life Sci 31: 29912998, 1982

Hara K, Minami K, Ueno S, Toyohira Y, Tsutsui M, Shigematsu A, Yanagihara N. Up-regulation of noradrenaline transporter in response to prolonged exposure to ketamine. Naunyn Schmiedeberg's Arch Pharmacol 365: 406-412, 2002

Hara K, Yanagihara N, Minami K, Ueno S, Toyohira Y, Sata T, Kawamura M, Bruss M, Bonisch H, Shigematsu A, Izumi F. Ketamine interacts with the noradrenaline transporter at a site partly overlapping the desipramine binding site. NaunynSchmiedeberg's Arch Pharmacol 358: 328-333, 1998

Harish OE, Kao LS, Raffaniello R, Wakade AR, Schneider AS. Calcium dependence of muscarinic receptor-mediated catecholamine secretion from the perfused rat adrenal medulla. $J$ Neurochem 48: 1730-1735, 1987

Hensel I, Braun U, Kettler D, Knoll D, Martel J, Paschen K. Studies on circulatory and metabolic changes during ketamine anaesthesia. Anaesthesist 21: 44-49, 1972

Idvall J, Ahlgren I, Aronsen KF, Stenberg P. Ketamine infusions: pharmacokinetics and clinical effects. $B r J$ Anaesth 51: 11671173, 1979

Ilno M. Calcium-induced calcium release mechanism in guinea pig taenia caeci. J Gen Physiol 94: 363-383, 1989

Inoue M, Kuriyama H. Muscarinic receptor is coupled with a cation channel through a GTP-binding protein in guinea-pig chromaffin cells. J Physiol (Lond) 436: 511-529, 1991

Juang MS, Yonemura K, Morita T, Tanaka T. Ketamine acts on 
the peripheral sympathetic nervous system of guinea pigs. Anesth Analg 59: 45-49, 1980

Kidokoro Y, Miyazaki S, Ozawa S. Acetylcholine-induced membrane depolarization and potential fluctuations in the rat adrenal chromaffin cell. J Physiol 324: 203-220, 1982

Kitagawa H, Yamazaki T, Akiyama T, Yahagi N, Kawada T, Mori H, Sunagawa K. Modulatory effects of ketamine on catecholamine efflux from in vivo cardiac sympathetic nerve endings in cats. Neurosci Lett 324: 232-236, 2002

Klose R, Peter K. Clinical studies on single-drug anesthesia using ketamine in patients with burns. Anaesthesist 22: 121-126, 1973

Knight DE, Baker PF. Observations on the muscarinic activation of catecholamine secretion in the chicken adrenal. Neuroscience 19: $357-366,1986$

Kolka MA, Elizondo RS, Weinberg RP. Sympathoadrenal responses to cold and ketamine anesthesia in the rhesus monkey. $J$ Appl Physiol 54: 896-900, 1983

Kreuscher H, Gauch H. The effect of phencylidine derivatives ketamine (CI 581) on the cardiovascular system of the man. Anaesthesist 16: 229-233, 1967

Ladona MG, Aunis D, Gandia AG, Garcia AG. Dihydropyridine modulation of the chromaffin cell secretory response. $J$ Neurochem 48: 483-490, 1987

Lanning CF, Harmel MH. Ketamine anesthesia. Annu Rev Med 26: $137-141,1975$

Lim DY, Hwang DH. Studies on secretion of catecholamines evoked by DMPP and McN-A-343 in the rat adrenal gland. Korean $J$ Pharmacol 27: 53-67, 1991

Lim DY, Kim CD, Ahn KW. Influence of TMB-8 on secretion of catecholamines from the perfused rat adrenal glands. Arch Pharm Res 15: 115-125, 1992

Mahmoodi V, Byrne AJ, HeaIy TE, Hussain SZ. Effect of ketamine on transmission in sympathetic ganglia. Br J Anaesth 52: 371375,1980

Maleque MA, Warnick JE, Albuquerque EX. The mechanism and site of action of ketamine on skeletal muscle. J Pharmacol Exp Ther 219: $638-645,1981$

McCarthy DA, Chen G, aup DH, Ensor C. General anesthetic and other pharmacological properties of 2-(O-chlorophenyl)-2methylamino cyclohexane HCl (CI-581). J New Drugs 5: 21-33, 1965

McGrath JC, MacKenzie JE, Millar RA. Circulatory responses to ketamine: dependence on respiratory pattern and background anaesthesia in the rabbit. Br J Anaesth 47: 1149-1156, 1975

Misbahuddin M, Isosaki M, Houchi H, Oka M. Muscarinic receptor-mediated increase in cytoplasmic free $\mathrm{Ca}^{2+}$ in isolated bovine adrenal medullary cells. Effects of TMB-8 and phorbol ester TPA. FEBS Lett 190: 25-28, 1985

Nakazato Y, Ohga A, Oleshansky M, Tomita U, Yamada Y. Voltage-independent catecholamine release mediated by the activation of muscarinic receptors in guinea-pig adrenal glands. Br J Pharmacol 93: 101-109, 1988

Oka M, Isosaki M, Yanagihara N. Isolated bovine adrenal medullary cells: studies on regulation of catecholamine synthesis and release. In: Usdin E, Kopin IJ, Brachas J ed, Catecholamines: Basic and Clinical frontiers. Pergamon Press, Oxford, p $70-72,1979$

Okamoto T, Okutani R, Tashiro C. The dual effect of ketamine on dopamine release from rat pheochromocytoma (PC-12) cells. Masui 45: 1083-1087, 1996

Purifoy JA, Holz RW. The effects of ketamine, phencyclidine and lidocaine on catecholamine secretion from cultured bovine adrenal chromaffin cells. Life Sci 35: 1851-1857, 1984

Rust M, Landauer B, Kolb E. Ketamine--a suitable agent for emergency situations. Anaesthesist 27: 205-212, 1978

Schwartz DA, Horwitz LD. Effects of ketamine on left ventricular performance. J Pharmacol Exp Ther 194: 410-414, 1975

Seidler NW, Jona I, Vegh N, Martonosi A. Cyclopiazonic acid is a specific inhibitor of the $\mathrm{Ca}^{2+}$-ATPase of sarcoplasimc reticulum. J Biol Chem 264: 17816-17823, 1989

Sumikawa K, Matsumoto T, Amenomori Y, Hkano H, Amakata Y. Selective actions of intravenous anesthetics on nicotinic- and muscarinic-receptor-mediated response of the dog adrenal medulla. Anesthesiology 59: 412-416, 1983

Suzuki M, Muraki K, Imaizumi Y, Watanabe M. Cyclopiazonic acid, an inhibitor of the sarcoplasmic reticulum $\mathrm{Ca}^{2+}$-pump, reduces $\mathrm{Ca}^{2+}$-dependent $\mathrm{K}^{+}$currents in guinea-pig smooth muscle cells. Br J Pharmacol 107: 134-140, 1992

Takara H, Wada A, Arita M, Sumikawa K, Izumi F. Ketamine inhibits ${ }^{45} \mathrm{Ca}$ influx and catecholamine secretion by inhibiting ${ }^{22} \mathrm{Na}$ influx in cultured bovine adrenal medullary cells. Eur $J$ Pharmacol 125: 217-224, 1986

Tallarida RJ, Murray RB. Manual of pharmacologic calculation with computer programs. 2nd ed. Speringer-Verlag, New York, p 132, 1987

Taube HD, Montel H, Hau G, Starke K. Phencyclidine and ketamine: comparison with the effect of cocaine on the noradrenergic neurones of the rat brain cortex. NaunynSchmiedeberg's Arch Pharmacol 291: 47-54, 1975

Traber DL, Wilson RD, Priano LL. Differentiation of the cardiovascular effects of CI-581. Anesth Analg 47: 769-778, 1968

Uceda G, Artalejo AR, Lopez MG, Abad F, Neher E, Garcia AG. $\mathrm{Ca}^{2+}$-activated $\mathrm{K}^{+}$channels modulate muscarinic secretion in cat chromaffin cells. J Physiol 454: 213-230, 1992

Uyama Y, Imaizumi Y, Watanabe M. Effects of cyclopiazonic acid, a novel $\mathrm{Ca}^{2+}$-ATPase inhibitor on contractile responses in skinned ileal smooth muscle. Br J Pharmacol 106: 208-214, 1992

Virtue RW, Alanis JM, Mori M, Lafargue RT, Vogal JHK, Metcalf DR. An anesthetic agent: 2-(O-chlorophenyl)-2-methylamino cyclohexane HCl (CI-581). Anesthesiology 28: 823-833, 1967

Volle RL, Alkadhi KA, Branisteanu DD, Reynolds LS, Epstein PM, Amilowitz H, Lambert JJ, Henderson EG. Ketamine and ditran block end-plate ion conductance and $\left[{ }^{3} \mathrm{H}\right]$ phencyclidine binding to electric organ membrane. J Pharmacol Exp Ther 221: 570576,1982

Wada A, Izumi F, Yanagihara N, Kobayashi H. Modulation by oubain and diphenylhydantoin of veratridine-induced ${ }^{22} \mathrm{Na}$ influx and its relation to ${ }^{45} \mathrm{Ca}$ influx and secretion of catecholamines in cultured bovine adrenal medullary cells. Naunyn-Schmiedberg's Arch Pharmacol 328: 273-278, 1985a

Wada A, Takara H, Izumi F, Kobayashi H, Yanagihara N. Influx of $22 \mathrm{Na}$ through acetylcholine receptor-associated $\mathrm{Na}$ channels: relationship between ${ }^{22} \mathrm{Na}$ influx, ${ }^{45} \mathrm{Ca}$ influx and secretion of catecholamines in cultured bovine adrenal medulla cells. Neuroscience 15: 283-292, 1985b

Wakade AR. Studies on secretion of catecholamines evoked by acetylcholine or transmural stimulation of the rat adrenal gland. $J$ Physiol 313: 463-480, 1981

Wieber J, Gugler R, Ohuchi T, Oka M. Pharmacokinetics of ketamine in man. Anesthesist 24: 260-283, 1975

Yamanaka I, Dowdy EG. The effects of ketamine on spiral-cut strips of rabbit aorta. Anesthesiology 40: 222-227, 1974 